\title{
Wiping Z-bending die design for precise part fabrication
}

\author{
Sutasn THIPPRAKMAS* and Arkarapon SONTAMINO** \\ * Department of Tool and Materials Engineering, King Mongkut's University of Technology Thonburi, Bangkok, Thailand \\ E-mail: sutasn.thi@kmutt.ac.th \\ ** Graduate student, Department of Tool and Materials Engineering, King Mongkut's University of Technology Thonburi, Bangkok, Thailand
}

Received: 25 November 2020; Revised: 19 January 2021; Accepted: 3 March 2021

\begin{abstract}
The use of Z-bent parts is increasing in many industrial fields. Moreover, the precision requirements for Z-bent part dimensions are becoming more stringent. Z-bent parts are commonly fabricated by two L- or V-bending processes, which cannot provide satisfactory precision. Therefore, a Z-bending process is needed. However, there are few studies on such processes, especially for asymmetrical Z-bent parts. In the present research, which is focused on the wiping Z-bending process, asymmetrical Z-bending die designs with asymmetrical bend radii and bend angles were investigated by using finite element method (FEM) simulations and laboratory experiments. The results showed that when fabricating the same $Z$-bent parts, different $Z$-bending die designs produced different stress distributions and different $Z$-bent part dimensions. Based upon the obtained results, the following die design recommendations were given. To fabricate asymmetrical bend radius Z-bent parts, the Zbending die should be designed with the larger bend radius on the punch side; however, the larger bend radius should be set on the die side when the accuracy of the large bend radius is of paramount importance. To fabricate asymmetrical bend angle Z-bent parts, the Z-bending die should be designed with the larger bend angle on the die side to provide better overall precision for the $Z$-bent part dimensions. To fabricate asymmetrical bend radius and bend angle Z-bent parts, the Z-bending die should be designed with the larger bend angle on the die side to provide better overall precision for the Z-bent part dimensions. This study confirmed that selecting a suitable Zbending die design is essential to fabricating precise $\mathrm{Z}$-bent parts.
\end{abstract}

Keywords : Z shape, Bending die design, Spring-back, Bend radius, Web thickness, Bend angle, Finite element method

\section{Introduction}

In recent years, competition in precision sheet-metal part forming has become increasingly intense in many industrial fields, such as the automotive, aerospace, electronics, and houseware industries. This competition is particularly strong for bent sheet-metal parts. Bent sheet-metal parts can be manufactured by sheet-metal bending processes. Such processes can be easily classified based on the bent parts (Lange, 1985). Most bent parts are L-, V-, U-, or Z-shaped, which are produced with L-, V-, U-, or Z-bending processes, respectively (Lange, 1985). In the past, most studies have been focused on L-, V-, and U-bending processes in an attempt to improve the quality of bent parts constructed with difficultto-form materials. In many studies, the finite element method (FEM) has been used for spring-back prediction to improve the quality of the obtained bend angle. D.M. Neto et al. performing FEM simulations of the bending process of mild steel (DC06) and dual-phase steel (DP600) to investigate the influence of boundary conditions on the prediction of springback and wrinkling (Neto et al., 2017). S. Thipprakmas investigated the mechanism of the coined bead in the V-bending process. The coined-bead functions increase in the reversed bending zones on the legs of the workpiece and result in an increase in the spring-go characteristics (Thipprakmas, 2011). Artificial neural network techniques have also been applied in bending process simulations to decrease time and computational cost. M.R. Jamli et al. incorporated a feedforward neural network within finite element analysis for spring-back prediction in the L-bending process (Jamli et al., 2015). O. Senol et al. performed a spring-back analysis in the air bending process through experiment-based artificial neural networks (Ozgu et al., 2014). Many studies have also examined the effects of material properties, tool shapes and bending 
temperatures on the spring-back characteristics and precision of bent parts constructed with difficult-to-form materials, such as aluminum alloy sheets (Thipprakmas and Boochakul, 2015), (Adnan et al., 2017), (Ren et al., 2017), (Phanitwong and Thipprakmas, 2016), (Wang et al., 2017), (Thipprakmas, 2013); high-strength low-alloy (HSLA) sheets (Ghaei et al., 2015), (Leu, 2017), (Zajkani and Hajbarati, 2017), (Saxena et al., 2017), (Jiang and Dai, 2015); and magnesium alloy sheets (Xie et al., 2015), (Duc-Toan et al., 2012). The effects of the bend angle and tool radius on the spring-back characteristics of aluminum alloy sheets (A1100-O, (JIS)) in the U-bending process were studied (Thipprakmas and Boochakul, 2015). A. Ghaei et al. (Ghaei et al., 2015) considered the nonlinear elastic unloading-reloading behavior while investigating the spring-back characteristics of advanced high-strength steels. H. Xie et al. investigated the influence of direct-current pulses on the spring-back characteristics of AZ31B magnesium alloy sheets during the Vbending process (Xie et al., 2015). In terms of Z-bent parts, in the past, the bending die has been designed based on Lor $\mathrm{V}$-bending theories, and the bent parts have usually been fabricated by applying two bending operations through the L- or V-bending process. However, this technique is not suitable for producing Z-bent parts with high precision requirements. Furthermore, it is expensive and time consuming due to the two bending operations needed. In recent years, there has been an increasing demand for high-precision Z-bent parts. This has emphasized that the Z-bending process must be improved; hence, many more studies need to be performed to generate new findings and insights. In the past, a few studies have investigated the Z-bending process (Thipprakmas and Komolruji, 2016), (Phanitwong et al., 2016), (Thipprakmas et al., 2018). However, the information gained from these studies has not been sufficient to achieve good Z-bending die design and fabricate precise Z-bent parts, especially asymmetrical Z-bent parts. The present research focuses on the wiping Z-bending process, as shown in Fig. 1. In this process, the workpiece is clamped on one side by a blank holder. The punch is moved downward to make contact with the workpiece, and then the workpiece is bent over the upper die radius. Next, the workpiece is bent again over the punch radius, and finally, the workpiece completely makes contact with the die, as shown in Fig. 1(b).

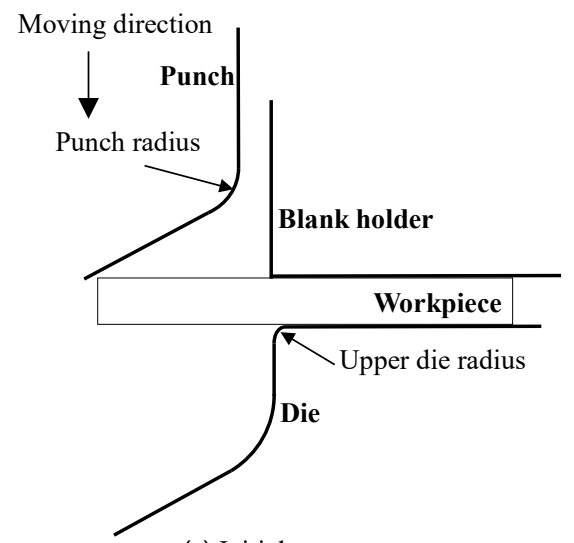

(a) Initial stage

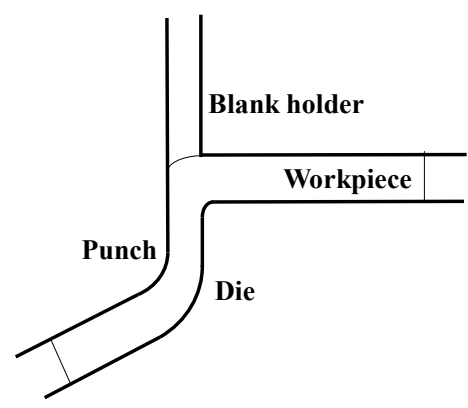

(b) Final stage before unloading

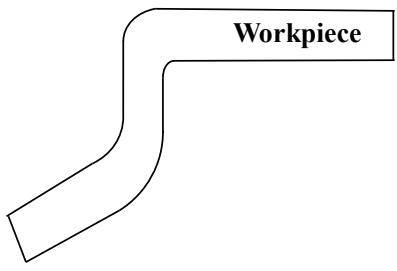

(c) Z-bent part

Fig. 1 A wiping Z-bending die model.

This process can make two bends in one stroke, thereby removing the need for a secondary bending operation and decreasing the time and cost of production (Cheok et al., 2002). In previous studies (Thipprakmas and Komolruji, 2016), (Phanitwong et al., 2016), (Thipprakmas et al., 2018), the bending mechanism and spring-back characteristics were investigated on asymmetrical Z-bent parts. The effects of the bend radius and bend angle on spring-back characteristics were clearly clarified through stress distribution analyses. However, no studies have investigated a suitable die design to achieve the high precision requirements of asymmetrical Z-bent parts. Asymmetrical Z-bent parts can have asymmetrical bend radii and asymmetrical bend angles. In Z-bent parts with an asymmetrical bend radius, as shown in Fig. 2(a-1), the bend angle is the same on each end, whereas the bend radius is different. In Z-bent parts with an asymmetrical bend angle, as shown in Fig. 2(b-1), the bend radius is the same on each end, whereas the bend angle is different. Two types of dies can be designed to fabricate these asymmetrical Z-bent parts with the wiping Z-bending process, as shown in Fig. 2. Specifically, Z-bending die design type I was designed by setting a larger bend radius and bend angle on the punch side and a smaller bend radius and bend angle on the die side. Conversely, Z-bending die design type II was designed by setting a larger bend radius and bend angle on the die side and a smaller bend radius and bend angle on the punch side. Therefore, determining a suitable wiping Z-bending die design is necessary to enable precise asymmetrical Z-bent part 
fabrication. In the present research, FEM simulations were used to investigate the wiping Z-bending die designs. Moreover, laboratory experiments were performed to validate the FEM simulation results. The FEM simulation results showed good agreement with the experimental results. The stress distribution results showed the differences in the bending characteristics before the unloading phase in the two wiping Z-bending die designs. These differences resulted in different $Z$-bent part dimensions, including bend radius, web thickness and bend angle. Therefore, carefully selecting a suitable wiping Z-bending die design is a major key to fabricating high-precision Z-bent parts. To fabricate Z-bent parts with an asymmetrical bend radius, the Z-bending die should be designed with the larger bend radius on the punch side. However, if the accuracy of the large bend radius is of paramount importance, the larger bend radius should be placed on the die side. To fabricate Z-bent parts with an asymmetrical bend angle, the Z-bending die should be designed with the larger bend angle on the die side to provide better overall precision for the Z-bent part dimensions. To fabricate Z-bent parts with an asymmetrical bend radius and an asymmetrical bend angle, the Z-bending die should be designed with the larger bend angle on the die side to provide better overall precision for the Z-bent part dimensions. Hence, it is very important to select a suitable Z-bending die design to ensure precise Z-bent part production.

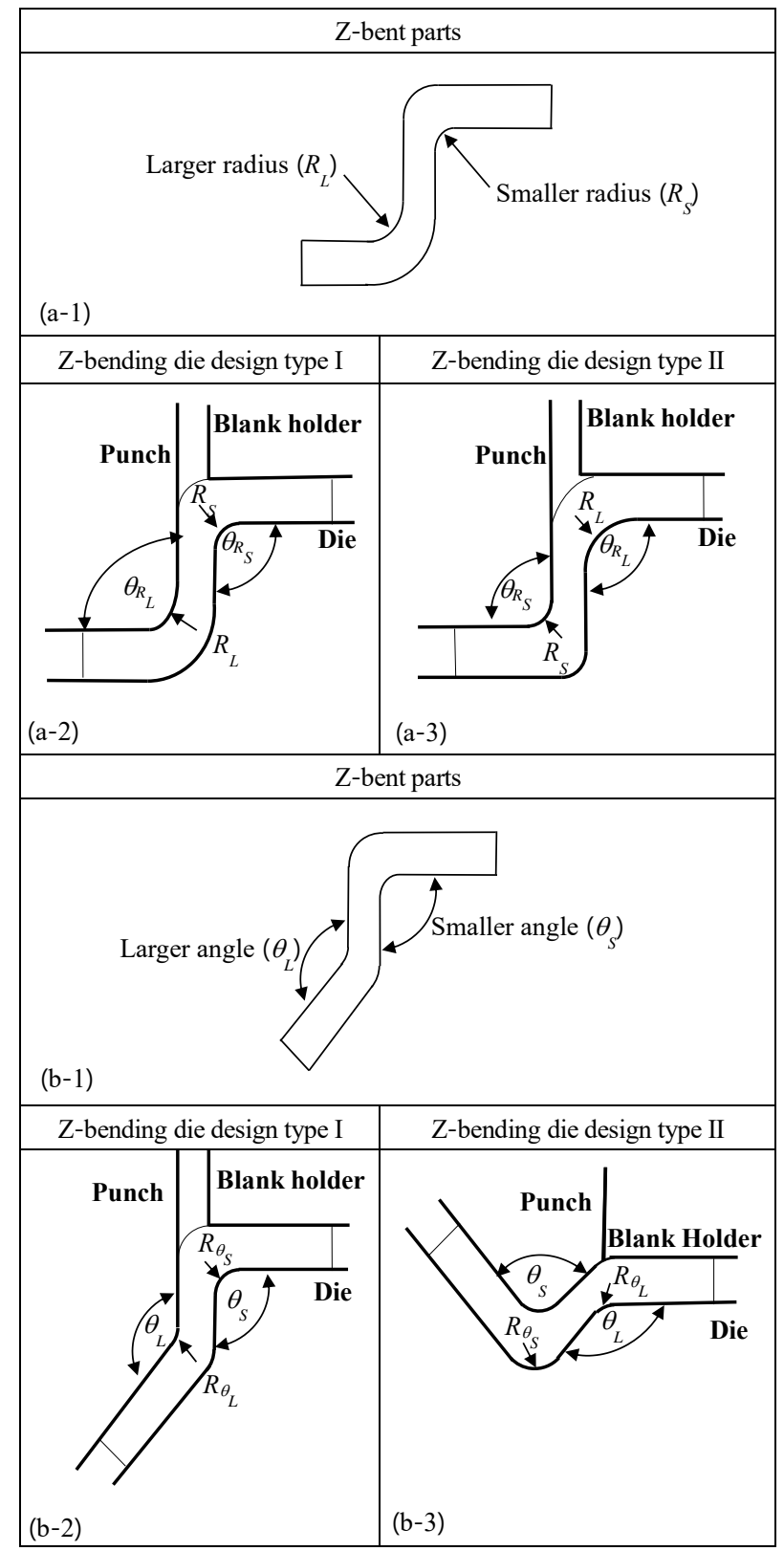

Fig. 2 Illustration of two different wiping Z-bending die designs. 


\section{FEM simulation and experiment procedures}

A model of the wiping Z-bending process investigated in this study is illustrated in Fig. 3. The important Z-bent part dimensions are the bend angle, web thickness, and bend radius; these dimensions for the asymmetrical bend radius and asymmetrical bend angle cases are depicted in Fig. 3(a-2) and (b-2), respectively. Table 1 lists the details of the model and the process parameters. Herein, the workpiece is a two-dimensional plane strain with a thickness of $3 \mathrm{~mm}$. Twodimensional, implicit, quasi-static FEM simulations were performed with DEFORM-2D. In accordance with previous studies (Phanitwong et al., 2016), (Thipprakmas et al., 2018), (Thipprakmas and Phanitwong, 2012), (Phanitwong and Thipprakmas, 2016), the punches, dies, and blank holders were modeled as rigid materials. The workpiece was modeled as an elastoplastic material, and it was meshed by approximately 4,000 rectangular elements. Due to excessive deformation of the elements, adaptive remeshing was performed every three steps to prevent calculation divergence. In the present research, aluminum A1100-O (JIS) was used as the workpiece material, and its properties were taken from tensile test data (Thipprakmas and Komolruji, 2016), (Phanitwong et al., 2016), (Thipprakmas et al., 2018). The other material properties are given in Table 1 , where E, $v$ and $\sigma_{\mathrm{u}}$ denote the Young modulus, Poisson's ratio and ultimate tensile stress, respectively. Based on the contact surface model defined by the Coulomb friction law, in accordance with previous research (Ghaei et al., 2015), (Leu, 2017), (Thipprakmas et al., 2018), friction coefficients ( $\mu$ ) of 0.10 were applied. The three investigated bend angles were $90^{\circ}, 120^{\circ}$, and $150^{\circ}$. Several bend angle combinations were investigated: $90^{\circ}-90^{\circ}$, $90^{\circ}-120^{\circ}, 90^{\circ}-150^{\circ}, 120^{\circ}-120^{\circ}, 120^{\circ}-150^{\circ}$, and $150^{\circ}-150^{\circ}$. Punch and die radii of $3,5,7$, and 9 mm were set. The other process parameters were designed as shown in Table 1. Laboratory wiping Z-bending experiments were performed to validate the FEM simulation results. Fig. 4 shows the wiping Z-bending die used for the experiments. A 5-ton universal testing machine (Lloyd Instruments Ltd.) was used as the press. Five samples for each bending condition were used to inspect the obtained bend angles, bend radii, and web thicknesses. After unloading, a profile projector (Mitutoyo model PJ-A3000) was used to measure the bend angle, bend radius, and web thickness. The average bend radius, bend angle and web thickness were calculated and reported. These average values were compared with those from the FEM simulations.

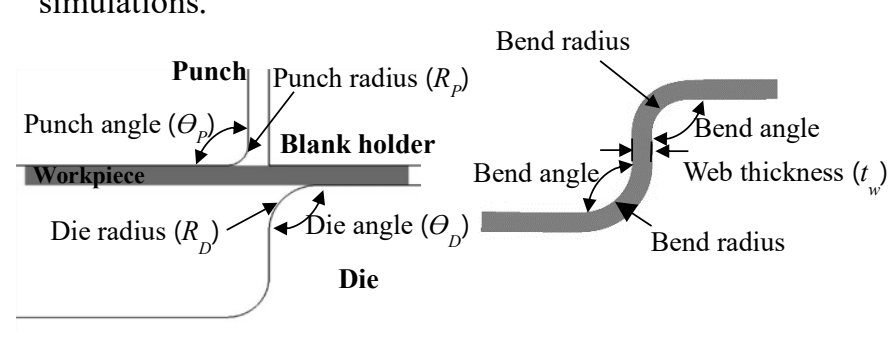

(a-1) Initial stage (a-2) Z-bent part

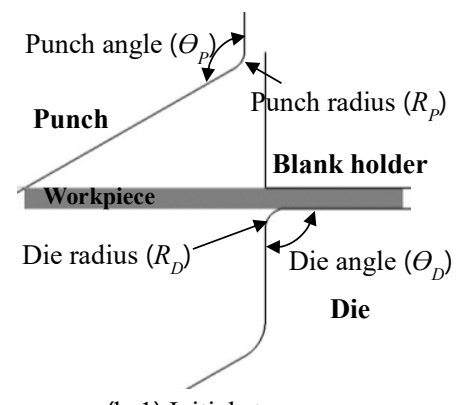

(b-1) Initial stage

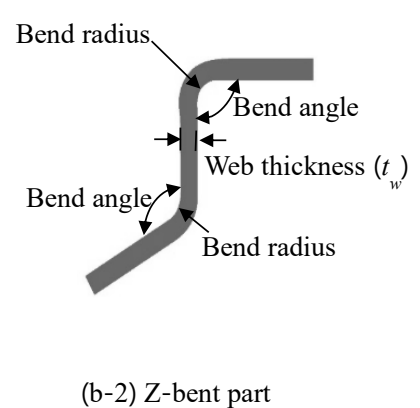

(b-2) Z-bent part

(a) Asymmetrical bend radius case

(b) Asymmetrical bend angle case

Fig. 3 Illustration of the investigated models of the wiping Z-bending process.

Table 1 FEM simulation and experimental conditions.

\begin{tabular}{|c|c|c|c|c|c|}
\hline & \multirow{2}{*}{\multicolumn{2}{|c|}{ Asymmetrical bend radius }} & \multirow{2}{*}{\multicolumn{2}{|c|}{ Asymmetrical bend angle }} \\
\hline & & & & & \\
\hline & & Type I & Type II & Type I & Type II \\
\hline \multirow{4}{*}{ 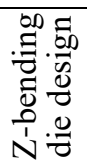 } & Die angle $\left(\Theta_{D}\right)$ & \multirow{2}{*}{\multicolumn{2}{|c|}{$90^{\circ}, 120^{\circ}, 150^{\circ}$}} & $90^{\circ}, 120^{\circ}$ & $120^{\circ}, 150^{\circ}$ \\
\hline & Punch angle $\left(\theta_{P}\right)$ & & & $120^{\circ}, 150^{\circ}$ & $90^{\circ}, 120^{\circ}$ \\
\hline & Die radius $\left(R_{D}\right)$ & $3,5 \mathrm{~mm}$ & $7,9 \mathrm{~mm}$ & \multirow{2}{*}{\multicolumn{2}{|c|}{$3,5,7 \mathrm{~mm}$}} \\
\hline & Punch radius $\left(R_{P}\right)$ & $7,9 \mathrm{~mm}$ & $3,5 \mathrm{~mm}$ & & \\
\hline \multicolumn{2}{|c|}{ Simulation model } & \multicolumn{4}{|c|}{ Plane strain model } \\
\hline \multicolumn{2}{|r|}{ Object type } & \multicolumn{4}{|c|}{$\begin{array}{l}\text { Workpiece: elastoplastic } \\
\text { Punch/die: rigid }\end{array}$} \\
\hline \multicolumn{2}{|c|}{ Workpiece material } & \multicolumn{4}{|c|}{$\begin{array}{c}\text { Young's modulus }(E): 68900 \mathrm{MPa} \\
\text { Poisson's ratio }(v): 0.33 \\
\text { Ultimate tensile strength }\left(\sigma_{u}\right): 92.50 \mathrm{MPa}\end{array}$} \\
\hline \multicolumn{2}{|c|}{ Flow stress equation } & \multicolumn{4}{|c|}{$\bar{\sigma}=153.5 \bar{\varepsilon}^{0.20}+88$} \\
\hline \multicolumn{2}{|c|}{ Workpiece thickness $(t)$} & \multicolumn{4}{|c|}{$3 \mathrm{~mm}$} \\
\hline \multicolumn{2}{|c|}{ Workpiece length $(l)$} & \multicolumn{4}{|c|}{$55 \mathrm{~mm}$} \\
\hline
\end{tabular}




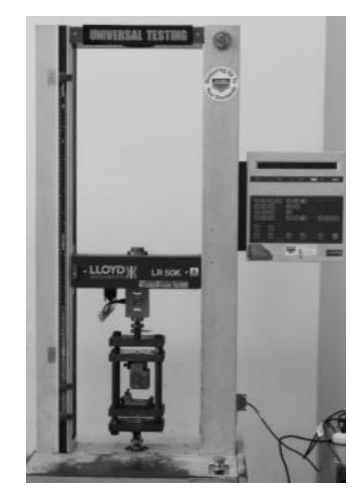

Fig. 4 Die set assembled on the universal testing machine.

\section{Results and discussion}

\subsection{Validation of the FEM simulation results}

In the present research, the FEM simulations were used to reduce the number of laboratory experiments. Therefore, the accuracy of the FEM simulations must be validated by comparing the bending forces and dimensions of the Z-bent parts, including the bend angle, bend radius and web thickness, from the FEM simulations with those obtained in the experiments. As shown in Fig. 5, the FEM simulation results and experimental results for the bending force were in good agreement. Furthermore, the predicted bend angle, bend radius, and web thickness corresponded well with the experimental results, as shown in Fig. 6. The error between the FEM simulation results and the experimental results was approximately $1 \%$.

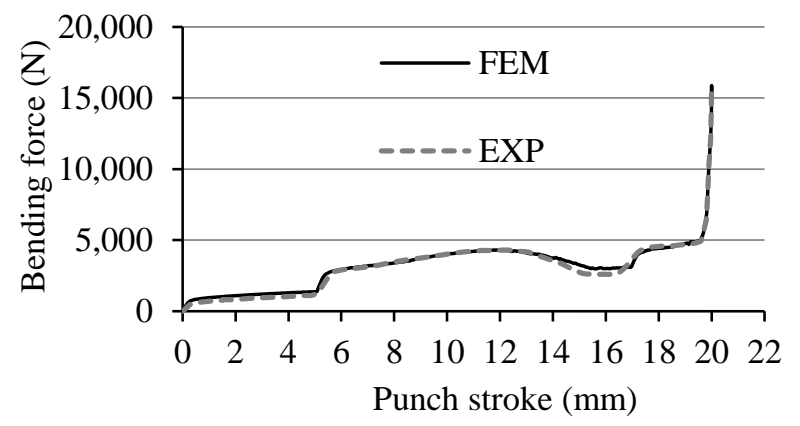

Fig. 5 Comparison of the bending force from the FEM simulations and experiments. $\left(\theta_{L}: 120^{\circ} ; \theta_{S}: 90^{\circ} ; R_{\theta L}: 3.00 \mathrm{~mm} ; R_{\theta S}: 3.00 \mathrm{~mm}\right)$

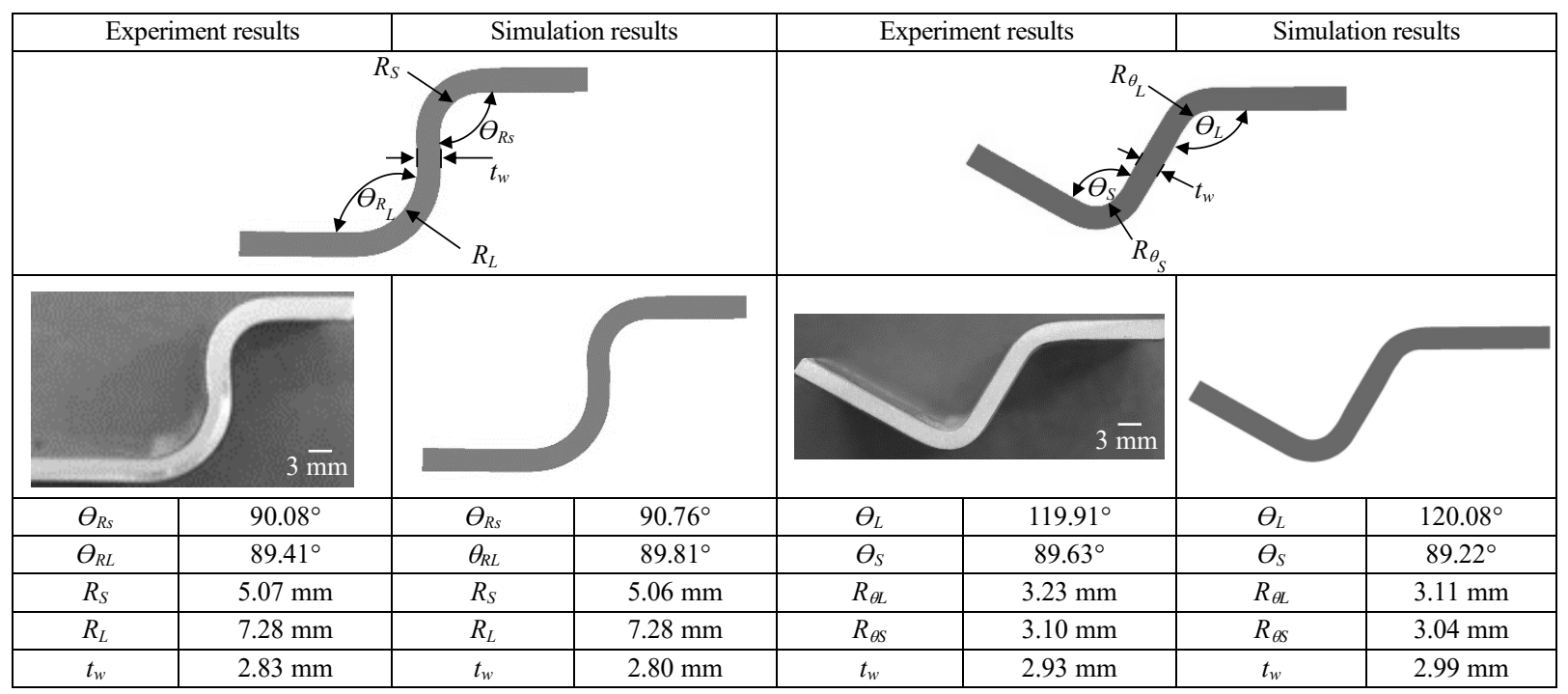

Fig. 6 Comparison of Z-bent part dimensions from the FEM simulations and experiments. 


\subsection{Comparison of stress distributions in different Z-bending die designs}

Fig. 7 shows a comparison of the stress distributions before the unloading phase in the different wiping Z-bending die designs for the cases with symmetrical and asymmetrical Z-bent parts. The case with symmetrical Z-bent parts is shown in Fig. 7(a). Although symmetrical Z-bent parts were formed, the stress distribution analysis revealed variations in punch and die radii. The variation in die radius occurred because one end was clamped over the die by the blank holder, no deformation could be generated, and the reversed bending stress could not be formed on this end. The variation in the punch radius occurred because the workpiece was not clamped on this end, resulting in deformation that could be freely generated, and the reversed bending stress was formed on this leg. The results from this stress distribution analysis generally agree with those reported in the literature (Phanitwong et al., 2016), (Thipprakmas et al., 2018). These stress distribution characteristics resulted in different dimensions in the punch and die sides of the Z-bent parts. The results confirm that even though symmetrical Z-bent parts were fabricated in every case, the precision of the part dimensions on the punch and die sides were variable. Spring-back is the main phenomenon governing the precision of Z-bent parts, especially for the bend angle. Furthermore, it is also closely related to the precision of the bend radius in Z-bent parts (Thipprakmas et al., 2020). As mentioned in the stress distribution analysis, after compensating for the bending and reversed bending stresses, spring-back was generated on the clamped end over the die, whereas spring-go was generated on the free end underneath the punch. For the Z-bent part after unloading, as shown in Fig. 7(a-3), the obtained bend angle and bend radius over the die radius were approximately $90.33^{\circ}$ and $2.88 \mathrm{~mm}$, respectively. In contrast, they were approximately $89.27^{\circ}$ and $3.67 \mathrm{~mm}$ over the punch radius, respectively. These results, in terms of asymmetrical Z-bent parts, strongly confirmed that the Z-bending die design must be appropriately considered because its design directly affects the precision of the dimensions in the punch and die sides of Z-bent part. In the case of asymmetrical Z-bent parts, as mentioned above, they were subdivided into asymmetrical bend radius and asymmetrical bend angle cases, as shown in Fig. 7(b) and (c), respectively. The results showed that the stress distributions in the bent parts over the punch and die radii were completely different for the two Z-bending die designs. For the cases with an asymmetrical bend radius, Zbending die type I was designed by setting the larger bend radius $\left(R_{L}\right)$ on the punch side and the smaller bend radius $\left(R_{S}\right)$ on the die side, as shown in Fig. 7(b-2). This figure shows the generated reversed bending stress on the end underneath the punch (zone A) and on the web (zone B) next to the bending allowance zone over the punch radius. The cases with asymmetrical Z-bent parts had a smaller reversed bending stress on the end underneath the punch and less spring-back generated on this side than the cases with symmetrical parts. In addition, the end over the die was constrained by the blank holder, and the workpiece was deformed by moving the punch downward during the bending phase. By setting the smaller bend radius over the die side and the larger bend radius over the punch side, the workpiece was pulled downward, and the material in the web zone thinned easily (Phanitwong et al., 2016), (Thipprakmas et al.,2018). Furthermore, material thinning was more easily generated in the bending allowance zone over the punch radius and caused poor bend radius dimensions. The asymmetrical bend radius $\mathrm{Z}$-bending die type II was designed by setting the larger bend radius $\left(R_{L}\right)$ on the die side and the smaller bend radius $\left(R_{S}\right)$ on the punch side, as shown in Fig. 7(b-3). In this case, the workpiece was moved downward by the punch more easily, and it rarely caused stretching on the web. This resulted in small material thinning over the web and rarely affected material thinning in the bending allowance zone over the punch radius. In addition, the stress distribution analysis on the web was separated into two zones, as shown in zone (C) and zone (D) in Fig. 7(b-3). Reversed bending stress zones (zone (C) and zone (E)) were generated next to the bending allowance zone over the punch radius, as shown in Fig. 7(b-3). These results from the stress distribution analysis generally agree with those reported in the literature (Phanitwong et al., 2016), (Thipprakmas et al., 2018). The reversed bending stress generated next to the bending allowance zone over the punch radius (zone (C)) was smaller in the case of asymmetrical Z-bent parts. This resulted in increases in spring-back on this end. In contrast, the reversed bending stress generated on the web next to the bending allowance zone over the die radius (zone (D)) decreased the spring-back on this end. These results clearly illustrate the different stress distributions in the asymmetrical bend radius Z-bending die designs. Different Z-bent part dimensions were formed when the Z-bending dies were designed with different asymmetrical bend radii. Specifically, for the type I and II asymmetrical bend radius Z-bending die designs, the predicted bend angles $\theta_{R S}$ and $\theta_{R L}$ were $90.68^{\circ}$ and $89.88^{\circ}$ and $89.30^{\circ}$ and $90.11^{\circ}$, respectively. For asymmetrical bend radius Z-bending die design type I, the predicted bend radii $R_{S}$ and $R_{L}$ were approximately $3.15 \mathrm{~mm}$ and $9.25 \mathrm{~mm}$, respectively, as shown in Fig. 7(b-4). For asymmetrical bend radius Z-bending die design type II, the predicted bend radii $R_{S}$ and $R_{L}$ were approximately $3.20 \mathrm{~mm}$ and $8.75 \mathrm{~mm}$, respectively, as shown in Fig. 7(b-5). 


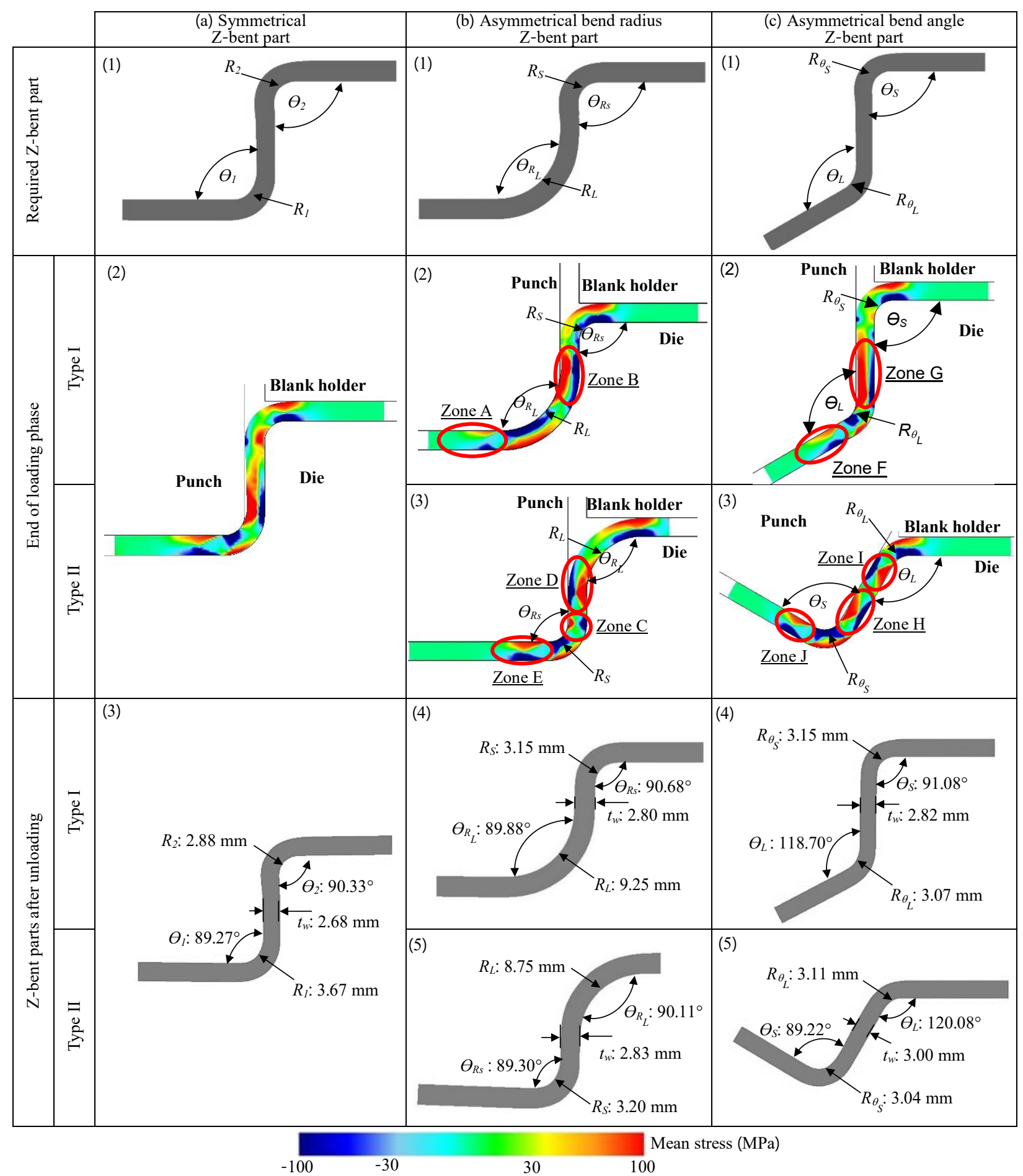

Fig. 7 Comparison of stress distributions and obtained Z-bent parts for the different wiping Z-bending die designs.

As mentioned above, with the stretching characteristics on the web and over the bend radius zones during the bending phase, the predicted web thickness was smaller for asymmetrical bend radius Z-bending die design type I than for asymmetrical bend radius Z-bending die design type II. Asymmetrical bend angle Z-bending die type I was designed by setting the larger bend angle $\left(\theta_{L}\right)$ on the punch side and the smaller bend angle $\left(\theta_{S}\right)$ on the die side, as shown in Fig. 7(c2). Asymmetrical bend angle $Z$-bending die type II was designed by setting the larger bend angle $\left(\theta_{L}\right)$ on the die side and the smaller bend angle $\left(\theta_{S}\right)$ on the punch side, as shown in Fig. 7(c-3). The stress distributions clearly varied when different asymmetrical bend angle Z-bending die designs were applied. The results showed that for asymmetrical bend angle Z-bending die type I, the workpiece was pulled downward, and the material on the web zone thinned more easily. These stress distribution analysis results generally agree with those reported in the literature (Phanitwong et al., 2016), (Thipprakmas et al., 2018). Furthermore, material thinning was also more easily generated in the bending allowance zone over the punch radius and caused poor bend radius dimensions. Reversed bending stresses were generated on the end 
over the punch radius (zone $\mathrm{F}$ ) and web (zone $\mathrm{G}$ ) next to the bending allowance zone over the punch radius, as shown in Fig. 7(c-2). Based on these stress distribution analyses, after compensating for these bending and reversed bending stress characteristics, spring-go was generated on the end over the punch, whereas spring-back was generated on the end over the die. For asymmetrical bend angle Z-bending die type II, as shown in Fig. 7(c-3), the workpiece was moved downward by the punch more easily and rarely caused stretching on the web. This resulted in small material thinning over the web and rarely affected material thinning in the bending allowance zone over the punch radius. In addition, the stress distribution on the web was separated into two zones, as shown in zone (H) and zone (I) in Fig. 7(c-3). These stress distribution results generally agree with those reported in the literature (Phanitwong et al., 2016), (Thipprakmas et al., 2018). Reversed bending stress zones (zone $(\mathrm{H})$ and zone $(\mathrm{J})$ ) were generated next to the bending allowance zone over the punch radius, as shown in Fig. 7(c-3). Based on these stress distribution analyses, after compensating for these bending and reversed bending stress characteristics, spring-go was generated on the end over the punch, whereas springback was generated on the end over the die. Again, these results confirmed the fact that different Z-bent part dimensions were formed with the different asymmetrical bend angle Z-bending dies. Specifically, as shown in Fig. 7(c-4) and (c-5), the predicted bend angle, bend radius, and web thickness were different when the Z-bending dies had different asymmetrical bend angles. Specifically, for the type I and II asymmetrical bend angle Z-bending die designs, the predicted bend angles $\theta_{S}$ and $\theta_{L}$ were $91.08^{\circ}$ and $118.70^{\circ}$ and $89.22^{\circ}$ and $120.08^{\circ}$, respectively. The results clearly showed that the spring-back and spring-go conditions were substantially different with the different asymmetrical bend angle Z-bending dies. For asymmetrical angle radius Z-bending die design type I, the predicted bend radii $R_{\theta S}$ and $R_{\theta L}$ were approximately $3.15 \mathrm{~mm}$ and $3.07 \mathrm{~mm}$, respectively, as shown in Fig. 7(c-4). For asymmetrical angle radius Z-bending die design type II, the predicted bend radii $R_{\theta S}$ and $R_{\theta_{L}}$ were approximately $3.04 \mathrm{~mm}$ and $3.11 \mathrm{~mm}$, respectively, as shown in Fig. 7(c-5). As mentioned above, with the stretching characteristics on the web and over the bend radius zones during the bending phase, the predicted web thickness was smaller for asymmetrical bend radius Z-bending die design type I than for asymmetrical bend radius Z-bending die design type II. Therefore, although the same Z-bent parts were fabricated with different Z-bending die designs, different bending mechanisms resulted in different generated bending and reversed bending stresses on the web and end. In addition, the stretching characteristics of the web and bend radius zones were different. This resulted in different predicted bend angles and different web thicknesses and bend radii after unloading. These results strongly confirmed that an appropriate wiping Z-bending die design should be selected to ensure good precision in Z-bent part fabrication.

\subsection{Asymmetrical bend radius $Z$-bending die design for fabricating precise $Z$-bent parts}

Table 2 lists the bending conditions and the FEM simulation results for the predicted Z-bent part dimensions, which were used to investigate the asymmetrical bend radius Z-bending die design.

Table 2 Illustration of the obtained asymmetrical bend radius Z-bent part geometries for the different wiping Z-bending die designs.

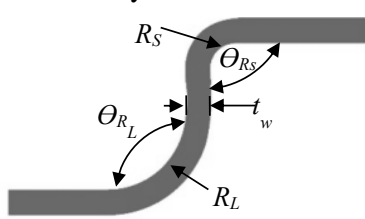

Type I

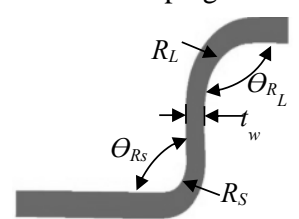

Type II

\begin{tabular}{|c|c|c|c|c|c|c|c|c|c|c|c|c|c|}
\hline \multirow{2}{*}{$\theta_{R \mathrm{~S}^{-}} \theta_{R L}$} & \multicolumn{6}{|c|}{ Type I } & \multirow{2}{*}{$\theta_{R \mathrm{~S}^{-}} \theta_{R L}$} & \multicolumn{6}{|c|}{ Type II } \\
\hline & $R_{S}-R_{L}$ & $\theta_{R \mathrm{~S}}$ & $\theta_{R L}$ & $R_{S}$ & $R_{L}$ & $t_{w}$ & & $R_{L}-R_{S}$ & $\theta_{R L}$ & $\theta_{R \mathrm{~S}}$ & $R_{L}$ & $R_{S}$ & $t_{w}$ \\
\hline \multirow{4}{*}{$90^{\circ}-90^{\circ}$} & $3-7$ & 90.44 & 89.71 & 18.3 & 21.7 & 2.80 & \multirow{4}{*}{$90^{\circ}-90^{\circ}$} & $7-3$ & 90.65 & 88.94 & 09.7 & 19.3 & 2.83 \\
\hline & $5-7$ & 90.56 & 89.81 & 06.5 & 28.7 & 2.80 & & $7-5$ & 90.89 & 89.52 & 15.7 & 23.5 & 2.83 \\
\hline & $3-9$ & 90.68 & 89.88 & 15.3 & 25.9 & 2.80 & & $9-3$ & 90.11 & 89.30 & 75.8 & 2.30 & 2.83 \\
\hline & $5-9$ & 90.66 & 89.84 & 02.5 & 32.9 & 2.80 & & $9-5$ & 90.18 & 89.58 & 73.8 & 19.5 & 2.83 \\
\hline \multirow{4}{*}{$120^{\circ}-120^{\circ}$} & $3-7$ & 120.00 & \begin{tabular}{|l|}
119.59 \\
\end{tabular} & 3.08 & 7.08 & 3.00 & \multirow{4}{*}{$120^{\circ}-120^{\circ}$} & $7-3$ & 120.45 & 119.02 & 7.05 & 3.22 & 3.00 \\
\hline & $5-7$ & \begin{tabular}{|l|}
120.31 \\
\end{tabular} & \begin{tabular}{|l|}
119.22 \\
\end{tabular} & 5.06 & 7.10 & 3.00 & & $7-5$ & 120.45 & 119.48 & 7.03 & 5.30 & 3.00 \\
\hline & $3-9$ & 120.08 & 119.73 & 3.10 & 9.10 & 3.00 & & $9-3$ & 120.67 & 119.14 & 9.10 & 3.12 & 3.00 \\
\hline & $5-9$ & 120.36 & 119.84 & 5.10 & 9.10 & 3.00 & & $9-5$ & 120.63 & 119.37 & 9.13 & 5.12 & 3.00 \\
\hline \multirow{4}{*}{$150^{\circ}-150^{\circ}$} & $3-7$ & \begin{tabular}{|l|}
149.76 \\
\end{tabular} & \begin{tabular}{|l|}
149.06 \\
\end{tabular} & 3.08 & 7.10 & 3.00 & \multirow{4}{*}{$150^{\circ}-150^{\circ}$} & $7-3$ & 150.33 & 149.21 & 7.04 & 3.10 & 3.00 \\
\hline & $5-7$ & \begin{tabular}{|l|}
149.91 \\
\end{tabular} & \begin{tabular}{|l|}
149.20 \\
\end{tabular} & 5.10 & 7.08 & 3.00 & & $7-5$ & 150.11 & 149.25 & 7.05 & 5.06 & 3.00 \\
\hline & $3-9$ & 149.89 & 149.48 & 3.06 & 9.12 & 3.00 & & $9-3$ & 150.53 & 149.01 & 9.05 & 3.08 & 3.00 \\
\hline & $5-9$ & 149.92 & 149.60 & 5.10 & 9.06 & 3.00 & & $9-5$ & 150.55 & 149.35 & 9.02 & 5.01 & 3.00 \\
\hline
\end{tabular}


The results showed that the predicted web thickness thinned at a bend angle of $90^{\circ}$ for both asymmetrical bend radius Z-bending dies. However, with the aforementioned material stretching characteristics on the web zone, the web thickness obtained from asymmetrical bend radius Z-bending die design type I was smaller than that obtained from asymmetrical bend radius Z-bending die design type II. When the bend angle was over $90^{\circ}$, the web thickness rarely thinned. This could be explained by the fact that as the bend angle increased, the workpiece could be more easily moved downward, and the material stretching characteristics could be delayed. The predicted large bend radius $\left(R_{L}\right)$ obtained from asymmetrical bend radius Z-bending die design type II was more accurate than that obtained from asymmetrical bend radius $Z$-bending die design type $I$. In contrast, the predicted small bend radius $\left(R_{S}\right)$ obtained from asymmetrical bend radius $Z$-bending die design type I was more accurate than that obtained from asymmetrical bend radius $Z$-bending die design type II. These results show that the predicted bend radius over the die side was more accurate than that over the punch side. This could be explained by the fact that in addition to the effects of spring-back characteristics, the material stretching characteristics affect the bending allowance zone over the punch radius, resulting in the larger bend radius being formed over the punch radius. As in the aforementioned stress distribution analysis, the predicted bend angles $\left(\theta_{R S}\right.$ and $\theta_{R L}$ ) from asymmetrical bend radius Z-bending die design type I were more accurate than those from asymmetrical bend radius $Z$-bending die design type II. These results indicate that asymmetrical bend radius $Z$-bending die type I should be selected to obtain more accurate overall Z-bent part dimensions. However, asymmetrical bend radius Zbending die type II should be selected when the accuracy of the large bend radius is of paramount importance.

\subsection{Asymmetrical bend angle $Z$-bending die design for fabricating precise $Z$-bent parts}

Table 3 lists the bending conditions and FEM simulation results of the predicted Z-bent part dimensions, which were used to investigate the asymmetrical bend angle Z-bending die design.

Table 3 Illustration of the obtained asymmetrical bend angle Z-bent part geometries for the different wiping Z-bending die designs.
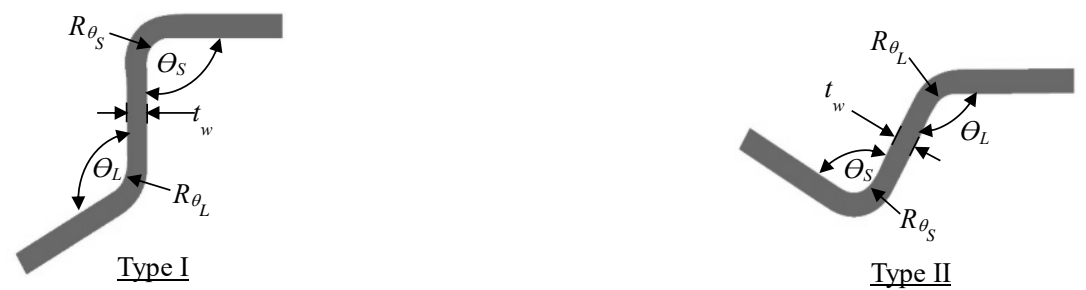

Type II

\begin{tabular}{|c|c|c|c|c|c|c|c|c|c|c|c|c|c|}
\hline \multirow{2}{*}{$R_{\theta \mathrm{S}}-R_{\theta \mathrm{L}}$} & \multicolumn{6}{|c|}{ Type I } & \multirow{2}{*}{$R_{\theta \mathrm{S}}-R_{\theta \mathrm{L}}$} & \multicolumn{6}{|c|}{ Type II } \\
\hline & $\theta_{S}-\theta_{L}$ & $\theta_{S}$ & $\theta_{L}$ & $R_{\theta \mathrm{S}}$ & $R_{\ell \mathrm{L}}$ & $t_{w}$ & & $\theta_{L}-\theta_{S}$ & $\theta_{L}$ & $\theta_{S}$ & $R_{\ell \mathrm{L}}$ & $R_{\theta \mathrm{S}}$ & $t_{w}$ \\
\hline \multirow{2}{*}{$3-3$} & $90^{\circ}-120^{\circ}$ & \begin{tabular}{|l|}
91.08 \\
\end{tabular} & $\begin{array}{ll}118.70 \\
\end{array}$ & 15.3 & 07.3 & 2.82 & \multirow{2}{*}{$3-3$} & $120^{\circ}-90^{\circ}$ & 120.08 & 89.22 & 11.3 & 04.3 & 3.00 \\
\hline & $120^{\circ}-150^{\circ}$ & \begin{tabular}{|l|}
119.78 \\
\end{tabular} & 148.9 & 3.10 & 3.10 & 3.00 & & $150^{\circ}-120^{\circ}$ & 149.85 & 119.09 & 04.3 & 07.3 & 3.00 \\
\hline \multirow{2}{*}{$5-5$} & $90^{\circ}-120^{\circ}$ & 91.72 & 118.91 & 02.5 & 03.5 & 2.84 & \multirow{2}{*}{$5-5$} & $120-90^{\circ}$ & 120.28 & 89.43 & 0.55 & 04.5 & 3.00 \\
\hline & $120^{\circ}-150^{\circ}$ & 120.39 & 149.01 & 5.10 & 05.5 & 3.00 & & $150^{\circ}-120^{\circ}$ & 149.99 & 119.78 & 05.5 & 07.5 & 3.00 \\
\hline \multirow{2}{*}{$7-7$} & $90^{\circ}-120^{\circ}$ & 91.96 & \begin{tabular}{|l|}
119.24 \\
\end{tabular} & 04.7 & 02.7 & 2.88 & \multirow{2}{*}{ 7-7 } & $120^{\circ}-90^{\circ}$ & 121.07 & 90.57 & 0.74 & 03.7 & 3.00 \\
\hline & $120^{\circ}-150^{\circ}$ & 120.88 & \begin{tabular}{|l}
149.45 \\
\end{tabular} & 7.10 & 08.7 & 3.00 & & $150^{\circ}-120^{\circ}$ & 150.18 & 120.18 & 01.7 & 04.7 & 3.00 \\
\hline
\end{tabular}

The results showed that the web thickness was thinning for asymmetrical bend angle Z-bending die design type I. The web thickness was thinning when the bend angle was $90^{\circ}$. Moreover, web thinning increased as the bend radius and bend angle decreased. Conversely, the web thickness rarely changed for asymmetrical bend angle Z-bending die design type II. For Z-bending die design type I, the smaller bend angle was set on the die side and the larger bend angle was set on the punch side, so the workpiece was pulled downward and the material on the web was more easily thinned (Phanitwong et al., 2016), (Thipprakmas et al., 2018). As the bend radius and bend angle increased, the workpiece moved downward more easily, and the changes in the material thinning decreased. The predicted bend angles and bend radii obtained from asymmetrical bend angle Z-bending die design type II were more accurate than those obtained from asymmetrical bend angle Z-bending die design type I. For asymmetrical bend angle Z-bending die design type II, the large bend angle was set on the punch side, which made it easier for material to flow and form the bend angle and bend radius over the punch radius. Therefore, the material stretching characteristics rarely affected the bending allowance zone and a precise bend radius could be achieved. Similarly, for asymmetrical bend angle Z-bending die design type II, the large bend angle was set on the die side, so the workpiece moved downward more easily, the material stretching characteristics rarely affected the bending allowance zone, and a precise bend radius could be achieved. As in the 
aforementioned stress distribution analysis, the predicted bend angles $\left(\theta_{S}\right.$ and $\left.\theta_{L}\right)$ from asymmetrical bend angle Zbending die design type II were more accurate than those from asymmetrical bend angle Z-bending die design type I. These results show that asymmetrical bend radius Z-bending die type II should be selected to obtain more accurate overall Z-bent part dimensions.

\subsection{Asymmetrical bend radius and bend angle $Z$-bending die design for fabricating precise $Z$-bent parts}

The asymmetrical bend radius and bend angle Z-bending die design to fabricate precise Z-bent parts was also investigated. Two types of asymmetrical Z-bent parts were investigated, as shown in Fig. 8.

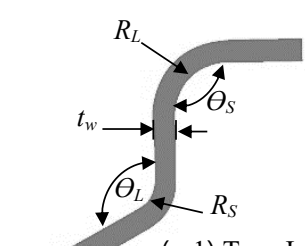

(a-1) Type I

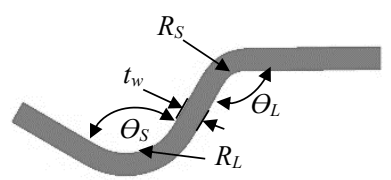

(a-2) Type II
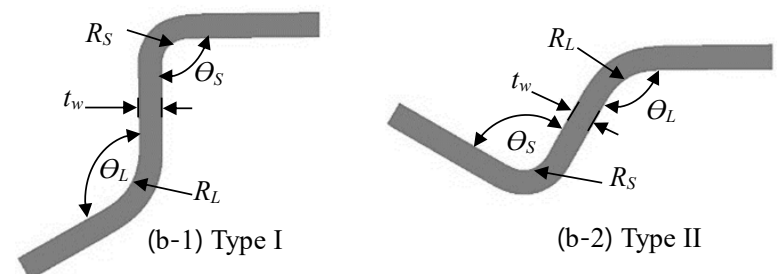

(b-2) Type II

(b) Large bend radius at a large bend angle and small bend radius at a small bend angle

(a) Large bend radius at a small bend angle and small bend radius at a large bend angle

Fig. 8 Illustration of the two investigated types of asymmetrical Z-bent parts.

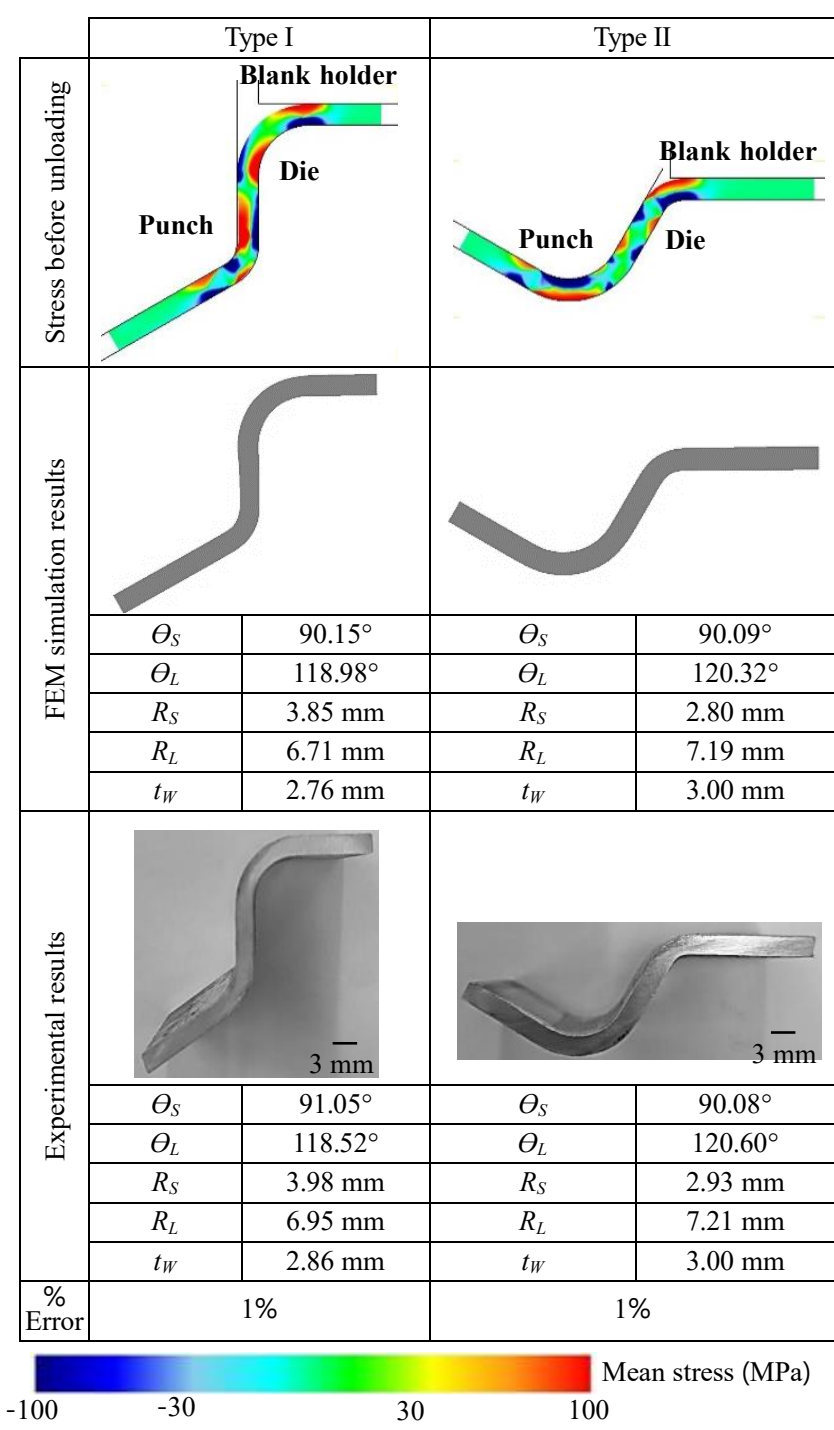

Fig. 9 Illustration of obtained asymmetrical bend angle Z-bent part geometries by setting the large bend radius at a large bend angle and the small bend radius at a small bend angle for the different wiping Z-bending die designs.

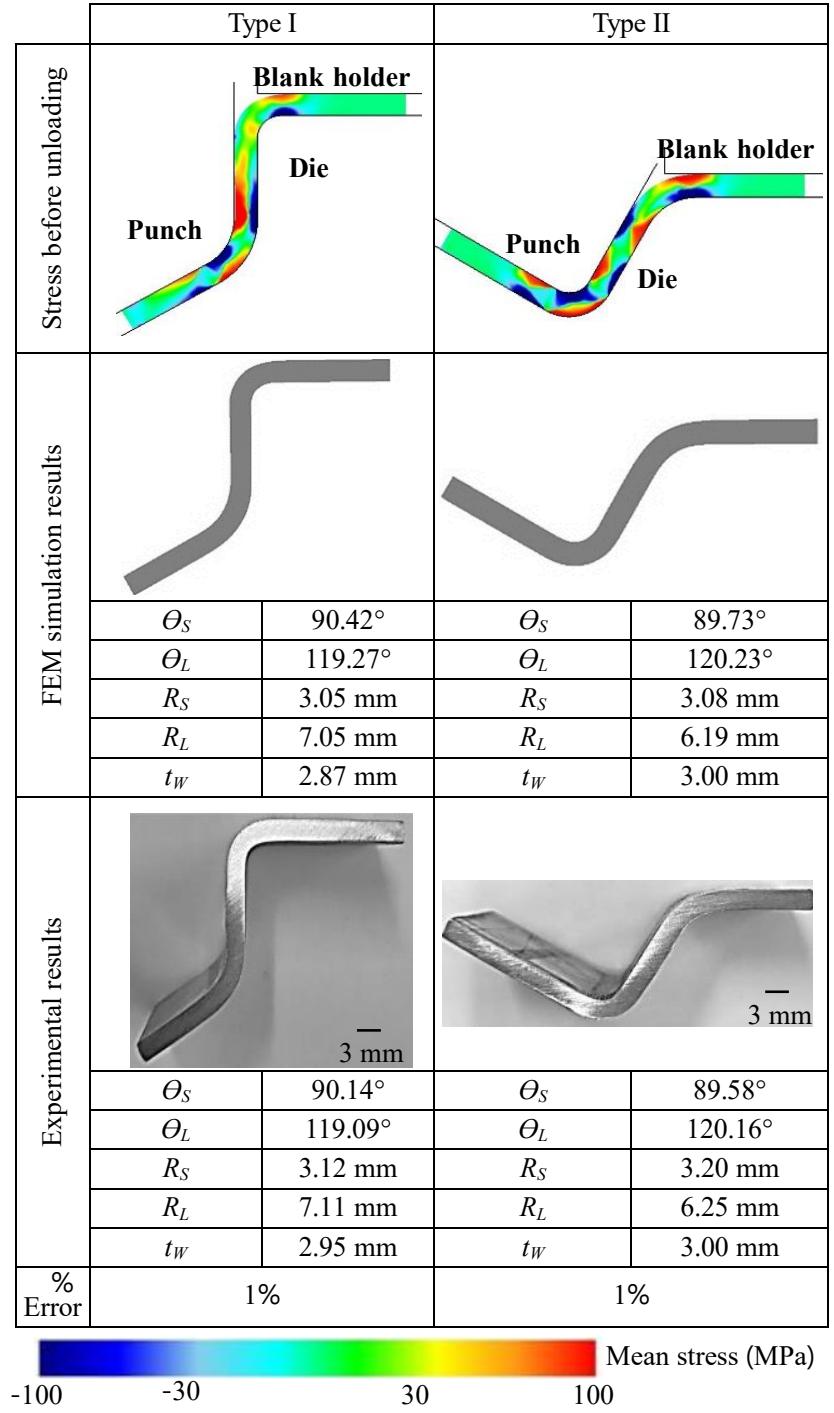

Fig. 10 Illustration of obtained asymmetrical bend angle Z-bent part geometries by setting the large bend radius at a small bend angle and the small bend radius at a large bend angle for the different wiping Z-bending die designs. 
Fig. 8(a) shows the case of a large bend radius at a small bend angle and a small bend radius at a large bend angle. Fig. 8(b) shows the case of a large bend radius at a large bend angle and a small bend radius at a small bend angle. As mentioned above, two types of Z-bending dies could be designed, as shown in Fig. 8. The predicted Z-bent part dimensions are shown in Fig. 9 and Fig. 10. These results show that the Z-bending die design with a larger bend angle on the die side should be selected to fabricate precise Z-bent parts. Moreover, the results show that the effects of the bend radius on precise Z-bent part dimensions were overcome by the effects of the bend angle. Specifically, the bend angle had strong effects on the material stretching characteristics, which decreased as the bend angle increased. More experiments were performed to validate the FEM simulation results. The experimental results are also shown in Fig. 9 and Fig. 10. The error between the FEM simulation results, including the bend angle, bend radius, and web thickness, and the laboratory experimental results was approximately $1 \%$. These results strongly confirmed that the asymmetrical bend radius $Z$-bending die design affected the precision of the Z-bent part dimensions. In the present research, asymmetrical bend angle Z-bending die type II should be selected to provide better overall precision for the Z-bent part dimensions.

\section{Conclusions}

In the present research, to achieve good precision for asymmetrical Z-bent parts fabricated by the wiping Z-bending process, relevant die designs were investigated by using FEM simulations and laboratory experiments. The analyzed bending forces and dimensions of the asymmetrical Z-bent parts, including the bend angle, bend radius, and web thickness, obtained from the FEM simulations were in good agreement with the experimental results. The results can be summarized as follows:

- To fabricate asymmetrical Z-bent parts by the wiping Z-bending process, two types of wiping Z-bending can be designed. For the type I design, the larger bend radius and bend angle are set on the punch side and the smaller bend radius and bend angle are set on the die side. For the type II design, the larger bend radius and bend angle are set on the die side and the smaller bend radius and bend angle are set on the punch side.

- On the basis of stress distribution analysis, different bending mechanisms and different stress distributions were generated with the different wiping Z-bending dies. Accordingly, the precision of the Z-bent part dimensions, including the bend angle, bend radius, and web thickness, varied.

- To fabricate asymmetrical bend radius Z-bent parts, the Z-bending die should be designed with the larger bend radius on the punch side (Type I) to obtain more accurate overall Z-bent part dimensions. However, Z-bending die type II should be selected when the accuracy of the large bend radius is of paramount importance.

- To fabricate asymmetrical bend angle Z-bent parts, the Z-bending die should be designed with the larger bend angle on the die side (Type II) to obtain better overall precision for the Z-bent part dimensions.

- To fabricate asymmetrical bend radius and bend angle $Z$-bent parts, the Z-bending die should be designed with the larger bend angle on the die side (Type II) to provide better overall precision for the Z-bent part dimensions.

Therefore, a suitable wiping Z-bending die design is very important for fabricating precise Z-bent parts.

\section{Acknowledgments}

This research was supported by The Thailand Research Fund (TRF) and King Mongkut's University of Technology Thonburi (grant no. RSA6180047). The authors would especially like to thank Wiriyakorn Phanitwong, Ph.D., Department of Industrial Engineering, Rajamangala University of Technology Rattanakosin, for her help in this research.

\section{References}

Adnan, M. F., Abdullah, A. B. and Samad, Z., 2017, Springback behavior of AA6061 with non-uniform thickness section using Taguchi Method, International Journal of Advanced Manufacturing Technology, Vol.89 (2017), pp. 20412052.

Cheok, B.T., Li, J.Y. and Nee, A.Y.C., Integrated feature-based modeling and process planning of bending operations in 
progressive die design, International Journal of Advanced Manufacturing Technology, Vol.20 (2002), pp.883-895.

Duc-Toan, N., Seung-Han, Y., Dong-Won, J., Tien-Long, B. and Young-Suk, K., A study on material modeling to predict spring-back in V-bending of AZ31 magnesium alloy sheet at various temperatures, International Journal of Advanced Manufacturing Technology, Vol.62 (2012), pp.551-562.

Ghaei, A., Green, D.E. and Aryanpour, A., Springback simulation of advanced high strength steels considering nonlinear elastic unloading-reloading behavior, Materials and Design, Vol. 88 (2015), pp.461-470.

Jamli, M.R., Ariffin, A.K. and Waha, D.A., Incorporating feedforward neural network within finite element analysis for L-bending springback prediction, Expert Systems with Applications, Vol.42 (2015), pp.2604-2614.

Jiang, H. J. and Dai, H. L., A novel model to predict U-bending springback and time-dependent springback for a HSLA steel plate, International Journal of Advanced Manufacturing Technology, Vol.81 (2015), pp.1055-1066.

Lange, K., Handbook of Metal Forming (1985), p.19.1-19.35, McGraw-Hill Inc.

Leu, D. K., Position deviation of bending point in asymmetric V-die bending process with HSS trapezoid sheet, International Journal of Advanced Manufacturing Technology, Vol.91 (2017), pp.3727-3735.

Neto, D.M., Oliveira, M.C., Santos, A.D., Alves, J.L. and Menezes, L.F., Influence of boundary conditions on the prediction of springback and wrinkling in sheet metal forming, International Journal of Mechanical Sciences, Vol.122 (2017), pp.244-254.

Ozgu S., Volkan E. and Haluk D., Springback analysis in air bending process through experiment based artificial neural networks, Procedia Engineering, Vol.81 (2014), pp.999-1004.

Phanitwong, W., Komolruji, P. and Thipprakmas, S., Finite Element Analysis of Spring-back Characteristics on Asymmetrical Z-shape Parts in Wiping Z-bending Process, The 6th International Conference on Simulation and Modeling Methodologies Technologies and Applications (SIMULTECH 2016).

Phanitwong, W. and Thipprakmas, S., Centered coined-bead technique for precise U-bent part fabrication, International Journal of Advanced Manufacturing Technology, Vol.84 (2016), pp.2139-2150.

Phanitwong, W. and Thipprakmas, S., Development of anew spring-back factor for a wiping die bending process, Materials and Design, Vol.89 (2016), pp.749-758.

Ren, D., Zhao, D., Fan, R., Zhao, K., Gang, S. and Chang, Y., Bending of sheet aluminum alloy assisted by arc pretreatment, International Journal of Advanced Manufacturing Technology, Vol.92 (2017), pp.1291- 1298.

Saxena, K. K., Das, I. M. and Mukhopadhyay, J., Evaluation of bending limit curves of aluminium alloy AA6014-T4 and dual phase steel DP600 at ambient temperature, International Journal of Material Forming, Vol.10 (2017), pp.221-231.

Thipprakmas, S., Spring- back factor applied for V-bending die design, Journal of Advanced Mechanical Design, Systems, and Manufacturing, Vol.14 No.3 (2020), DOI: 10.1299/jamdsm.2020jamdsm0037.

Thipprakmas, S., Finite element analysis of sided coined-bead technique in precision V-bending process, International Journal of Advanced Manufacturing Technology, Vol.65 (2013), pp.679-688.

Thipprakmas, S., Finite element analysis on the coined-bead mechanism during the V-bending process, Materials and Design, Vol.32 (2011), pp.4909-4917.

Thipprakmas, S. and Boochakul, U., Comparison of spring-back characteristics in symmetrical and asymmetrical Ubending processes, International Journal of Precision Engineering and Manufacturing, Vol.16 (2015), pp.1441-1446.

Thipprakmas, S. and Komolruji, P., Analysis of bending mechanism and spring-back characteristics in the offset Zbending process, International Journal of Advanced Manufacturing Technology, Vol.85 (2016), pp.2589-2596.

Thipprakmas, S., Komolruji, P. and Phanitwong, W., Comparison of offset and wiping Z-die designs for precision Zbent part fabrication, Journal of Manufacturing Science and Engineering, Vol.140 (2018).

Thipprakmas ,S. and Phanitwong, W., Finite element analysis of flange-forming direction in the hole flanging process, International Journal of Advanced Manufacturing Technology, Vol.61 (2012), pp.609-620.

Wang, A., Zhong, K., Fakir, O. E., Liu, J., Sun, C., Wang, L. L., Lin, J. and Dean, T. A., Springback analysis of AA5754 after hot stamping: experiments and FE modelling, International Journal of Advanced Manufacturing Technology, Vol.89 (2017), pp.1339-1352.

Xie, H., Wang, Q., Liu, K., Peng, F., Dong, X., and Wang, J., Investigation of influence of direct-current pulses on springback during V-bending of AZ31B magnesium alloy sheet, Journal of Materials Processing Technology, Vol.219 (2015), pp.321-327.

Zajkani,A. and Hajbarati, H., An analytical modeling for springback prediction during U-bending process of advanced high-strength steels based on anisotropic nonlinear kinematic hardening model, International Journal of Advanced Manufacturing Technology, Vol.90 (2017), pp.349-359. 